\title{
PERSEPSI DAN KESIAPAN MENIKAH PADA MAHASISWA
}

\author{
Diah Krisnatuti $^{1^{*}}$, Vivi Oktaviani ${ }^{1}$ \\ ${ }^{1}$ Departemen IImu Keluarga dan Konsumen, Fakultas Ekologi Manusia, Institut Pertanian Bogor, \\ Bogor 16680, Indonesia \\ ${ }^{*}$ E-mail: diahkp@yahoo.com
}

\begin{abstract}
Abstrak
Penelitian ini bertujuan untuk menganalisis hubungan antarvariabel penelitian dan pengaruh karakteristik mahasiswa, keterpaparan informasi, faktor stimulus, dan pengetahuan tentang pernikahan terhadap persepsi dan kesiapan menikah pada mahasiswa. Penelitian ini melibatkan 72 mahasiswa yang dipilih dengan menggunakan teknik convenient sampling. Pengumpulan data dilakukan melalui wawancara dan diolah dengan menggunakan uji beda, uji korelasi, dan uji regresi. Hasil penelitian menunjukkan bahwa pengetahuan tentang pernikahan berhubungan signifikan dengan usia, jenis kelamin, dan prestasi akademik. Persepsi tentang pernikahan berhubungan signifikan dengan jumlah saudara dan kebiasaan berdiskusi. Persepsi tentang pernikahan dipengaruhi oleh jumlah saudara, diskusi pernikahan dengan teman, dan pacar. Kesiapan menikah berhubungan signifikan dengan frekuensi memperoleh informasi tentang pernikahan. Sementara itu, kesiapan menikah dipengaruhi oleh usia, jumlah penyakit yang diderita, dan cara untuk mengelola rumah tangga.
\end{abstract}

\section{Perception and Marriage Readiness of College Students}

\begin{abstract}
This research aimed to analyze the correlation between research variables and the influence of college student characteristics, exposure informations, stimulus factors, and knowledge about marriage toward perception and marriage readiness. This research involved 72 college students that were selected by convenient sampling technique. The data was collected through interviews and analyzed using different test, correlation test, and regression test. Research results showed that knowledge about marriage correlated significant with age, sex, and academic achievement. Perception about marriage correlated significant with number of sibling and discussion habit. Perception about marriage was influenced by number of sibling, marriage discussion with friend, and boyfriend. Marriage readiness correlated significant with frequency to obtain information about marriage. Meanwhile, marriage readiness was influenced by students age, number of disease suffered, and the way to manage the household.
\end{abstract}

Key words: exposure informations, marriage knowledge, marriage readiness, perception, stimulus factors

\section{PENDAHULUAN}

Pernikahan merupakan awal terbentuknya kehidupan keluarga. Setiap pasangan yang mengikrarkan diri dalam sebuah ikatan pernikahan tentu berharap agar pernikahan yang dibangun berhasil. Salah satu penyebab gagalnya pasangan dalam mempertahankan pernikahan dan mewujudkan kebahagiaan adalah terbatasnya upaya persiapan pernikahan yang dilakukan.

Kennedi (2005) menjelaskan ada enam upaya persiapan pernikahan yang perlu dilakukan. Upaya tersebut adalah siapa dan bagaimana keadaan kedua pasangan sebelum memasuki kehidupan keluarga, kesehatan jasmani dan rohani kedua pasangan ketika memasuki kehidupan pernikahan, pemahaman kedua pasangan tentang kehidupan pernikahan dan berkeluarga, suasana keluarga tempat kedua pasangan dibesarkan, kondisi sosial budaya dan ekonomi keluarga, dan keyakinan hidup beragama.

Keinginan untuk menikah dan membina rumah tangga yang tidak diimbangi oleh pengetahuan tentang pernikahan dan kehidupan keluarga dapat menimbulkan permasalahan di kemudian hari. Kebanyakan orang yang menyatakan dirinya belum siap menikah hanya menjadikan penghasilan sebagai alasan. Kecenderungan berfikir alasan ekonomi sebagai satu-satunya ukuran kesiapan menikah menjadi hal yang perlu diluruskan. Kondisi yang terjadi saat ini seperti kurangnya perhatian masyarakat akan pentingnya pengetahuan pernikahan, semakin tingginya tingkat perceraian, dan semakin majemuknya masalah-masalah di dalam keluarga menjadi 
alasan terbentuknya konseling pranikah (Puspitasari, 1997).

Pengetahuan tentang pernikahan menjadi dasar terbentuknya persepsi terhadap pernikahan. Pengetahuan tentang pernikahan ini dapat diperoleh dari keluarga, teman, atau pengalaman orang lain (Putrini, 2002). Pengetahuan yang baik mengenai pernikahan akan membentuk persepsi yang positif terhadap pernikahan. Persepsi tentang pernikahan merupakan hal yang sangat penting karena merupakan fondasi awal yang harus dipersiapkan dalam membangun kehidupan keluarga (Hawa, 2007).

Walgito (1989), diacu dalam Maria (2007) menjelaskan bahwa ada dua faktor yang mempengaruhi terjadinya persepsi yaitu keadaan individu dan keadaan objek yang dipersepsikan. Persepsi juga berkaitan dengan faktor yang ada di luar individu seperti keterpaparan informasi dan faktor stimulus (teman sebaya dan keluarga). Teman sebaya dan keluarga ini akan membantu terbentuknya persepsi.

Pengetahuan dan persepsi yang baik mengenai pernikahan akan berimplikasi pada kesiapan menikah. Kesiapan menikah merupakan kesediaan individu untuk mempersiapkan diri membentuk suatu ikatan lahir batin antara seorang pria dan wanita sebagai suami isteri dengan tujuan membentuk keluarga dan rumah tangga yang kekal dan diakui secara agama, hukum, dan masyarakat (Dewi, 2006).

Berdasarkan pemaparan tersebut, diketahui bahwa kesiapan menikah berkaitan dengan pengetahuan, persepsi, keterpaparan informasi, dan faktor stimulus. Untuk itu, penelitian ini bertujuan untuk menganalisis hubungan antarvariabel penelitian dan pengaruh karakteristik mahasiswa, keterpaparan informasi, faktor stimulus, dan pengetahuan tentang pernikahan terhadap persepsi dan kesiapan menikah pada mahasiswa.

\section{METODE}

Disain penelitian yang digunakan adalah disain cross sectional study dengan lokasi penelitian di Kampus Dramaga, Institut Pertanian Bogor (IPB). Pemilihan Iokasi penelitian dilakukan secara purposive. Waktu penelitian dilakukan mulai bulan Juni 2009 sampai April 2010. Mahasiswa yang menjadi partisipan dalam penelitian ini (partisipan) adalah mahasiswa IPB yang dipilih secara convenience. Mahasiswa yang terlibat berjumlah 72 mahasiswa yang terdiri atas 36 mahasiswa laki-laki dan 36 mahasiswa perempuan.

Data primer terdiri atas karakteristik mahasiswa, keterpaparan informasi, faktor stimulus, pengetahuan tentang pernikahan, persepsi terhadap pernikahan, serta kesiapan menikah. Data dikumpulkan melalui wawancara dengan bantuan kuesioner penelitian. Pertanyaan yang digunakan dalam kuesioner berupa pertanyaan tertutup, pertanyaan terbuka, dan kombinasi keduanya.

Karakteristik mahasiswa terdiri atas usia, jenis kelamin, agama, suku, jumlah saudara, jalur masuk IPB, Indeks Prestasi Kumulatif (IPK), uang saku, riwayat penyakit, pengalaman organisasi, dan prioritas menikah. Usia partisipan dikelompokkan dalam tiga kategori yaitu usia 20 tahun, 21 tahun, dan 22 tahun. Jenis kelamin partisipan terdiri atas laki-laki dan perempuan. Agama yang dianut partisipan dibedakan menjadi agama Islam dan nonIslam. Suku terdiri atas Batak, Minang, Betawi, Sunda, Jawa, Bugis, dan Melayu. Jumlah saudara dikategorikan dalam tiga kategori yaitu kecil (< 3 orang), sedang (3-5 orang), dan besar (> 5 orang).

Jalur masuk IPB terdiri atas USMI, SPMB, dan BUD. Indeks Prestasi Kumulatif (IPK) dikategorikan dalam tiga kategori yaitu memuaskan ( $\leq 2,75)$, sangat memuaskan $(2,76-3,49)$, dan cum laude $(\geq 3,5)$. Uang saku di-kategorikan dalam tiga kategori yaitu rendah (uang saku < Rp500.000,00), sedang (uang saku Rp500.000,00-Rp1.000.000,00), dan tinggi (uang saku > Rp1.000.000,00). Riwayat penyakit dikategorikan dalam dua kategori yaitu pernah dan tidak pernah menderita penyakit. Kegiatan organisasi terdiri atas ikut dan tidak ikut kegiatan organisasi. Prioritas menikah diukur berdasarkan urutan, yaitu urutan pertama, urutan kedua, urutan ketiga, dan urutan keempat.

Keterpaparan informasi diukur berdasarkan sumber informasi dan frekuensi. Sumber informasi dikategorikan dalam enam kategori yaitu media massa, keluarga, teman, dosen, mimbar agama, dan tetangga. Kesesuaian informasi yang diperoleh dengan kebutuhan dikategorikan menjadi sesuai dan tidak sesuai. Frekuensi keterpaparan informasi dikategorikan dalam empat kategori yaitu selalu (setiap hari), sering (tiga sampai dengan empat hari sekali dalam seminggu), kadang-kadang (dua minggu sekali), dan tidak tentu ( $\geq$ satu bulan sekali). Sementara itu, faktor stimulus 
dalam penelitian ini dibedakan berdasarkan sumber yaitu stimulus yang diperoleh dari teman sebaya dan keluarga.

Pengetahuan tentang pernikahan diukur melalui 15 pertanyaan dengan skor 1 untuk jawaban benar dan 0 untuk jawaban salah. Selanjutnya berdasarkan skor yang diperoleh, pengetahuan tentang pernikahan dikategorikan dalam tiga kategori berdasarkan skor yang sudah dipersentasekan yaitu kurang, sedang, dan baik. Instrumen yang digunakan untuk mengukur pengetahuan tentang pernikahan telah reliabel dengan nilai Cronbach's alpha sebesar 0,765 .

Persepsi mahasiswa terhadap pernikahan diukur melalui 18 pernyataan dengan kisaran skor jawaban antara 1 (sangat tidak setuju) sampai 5 (sangat setuju). Selanjutnya, persepsi dikategorikan dalam tiga kategori skor yang sudah dipersentasekan yaitu kurang, sedang, dan baik. Instrumen yang digunakan untuk mengukur persepsi terhadap pernikahan telah reliabel dengan nilai Cronbach's alpha sebesar 0,811 .

Kesiapan menikah diukur melalui 30 pernyataan dengan kisaran skor jawaban antara 1 (satu) sampai 3 (tiga). Selanjutnya, kesiapan menikah dikategorikan dalam tiga kategori skor yang sudah dipersentasekan yaitu belum siap menikah, cukup siap menikah, dan siap menikah. Instrumen yang digunakan untuk mengukur kesiapan menikah telah reliabel dengan nilai Cronbach's alpha sebesar 0,909.

Data yang telah dikumpulkan diolah dan dianalisis. Analisis deskriptif dilakukan untuk mengukur nilai rata-rata dan standar deviasi variabel penelitian. Uji beda Mann Whitney dilakukan untuk menganalisis perbedaan variabel penelitian berdasarkan jenis kelamin. Hubungan antarvariabel penelitian dianalisis dengan menggunakan uji Chi-square dan korelasi Spearman. Sementara itu, uji regresi linear berganda dilakukan untuk menganalisis pengaruh karakteristik mahasiswa, keterpaparan informasi, faktor stimulus, dan pengetahuan tentang pernikahan terhadap persepsi dan kesiapan menikah pada mahasiswa.

\section{HASIL}

Karakteristik Partisipan. Hasil penelitian menunjukkan bahwa satu dari dua partisipan berusia 21 tahun. Proporsi partisipan berdasarkan jenis kelamin adalah sama. Sebagian besar partisipan dalam penelitian ini $(97,2 \%)$ beragama Islam dan sisanya $(2,8 \%)$ beragama selain Islam. Proporsi terbesar partisipan berasal dari suku Jawa $(47,2 \%)$ dan suku Sunda $(30,6 \%)$. Berdasarkan jumlah saudara, tiga dari lima partisipan memiliki jumlah saudara dalam kategori sedang (3-5 orang). Sementara itu, berdasarkan jalur masuk IPB, sebagian besar partisipan $(72,2 \%)$ diterima melalui jalur Undangan Seleksi Masuk IPB (USMI). Dua dari tiga partisipan memiliki IPK pada kategori sangat memuaskan $(2,76-3,49)$.

Hasil penelitian juga menunjukkan bahwa tujuh dari sepuluh uang saku partisipan bersumber dari orang tua atau wali dengan kisaran dari Rp100.000,00 sampai dengan Rp1.250.000,00 per bulan. Sebagian besar partisipan $(84,7 \%)$ menyatakan pernah menderita beberapa jenis penyakit, antara lain maag, radang, thypus, demam berdarah, dan asma. Partisipan juga aktif mengikuti kegiatan organisasi dalam dan luar kampus $(97,2 \%)$.

Berdasarkan aspek prioritas menikah, hasil penelitian menunjukkan bahwa satu dari dua partisipan dalam penelitian ini memprioritaskan menikah pada urutan kedua. Jika dilihat berdasarkan jenis kelamin, partisipan yang berjenis kelamin perempuan memilih menikah sebagai prioritas kedua $(55,6 \%)$, sedangkan partisipan yang berjenis kelamin laki-laki cenderung memilih menikah pada prioritas ketiga $(47,2 \%)$.

Tabel 1 Sebaran partisipan berdasarkan keterpaparan informasi

\begin{tabular}{lrrr}
\hline \multicolumn{1}{c}{ Kategori } & $\begin{array}{c}\mathrm{L} \\
(\mathrm{n}=36)\end{array}$ & $\begin{array}{c}\mathrm{P} \\
(\mathrm{n}=36)\end{array}$ & $\begin{array}{c}\text { Total } \\
(\mathrm{n}=72)\end{array}$ \\
\hline $\begin{array}{l}\text { Sumber informasi* } \\
\text { Media massa }\end{array}$ & 86,1 & 88,9 & 87,5 \\
Keluarga & 50,0 & 75,0 & 62,5 \\
Teman & 66,7 & 75,0 & 70,8 \\
Dosen & 16,7 & 36,1 & 26,4 \\
Mimbar agama & 38,9 & 38,9 & 38,9 \\
Tetangga & 2,8 & 0,0 & 1,4 \\
\hline $\begin{array}{l}\text { Frekuensi } \\
\text { Selalu (setiap }\end{array}$ & & & \\
hari) & 8,3 & 13,9 & 11,1 \\
$\begin{array}{l}\text { Sering (3-4 hari } \\
\text { sekali) }\end{array}$ & 25,0 & 13,8 & 19,4 \\
$\begin{array}{l}\text { Kadang-kadang } \\
\text { (2 minggu sekali) }\end{array}$ & 33,3 & 16,7 & 25,0 \\
$\begin{array}{l}\text { Tidak Tentu ( } \geq 1 \\
\text { bulan sekali) }\end{array}$ & 33,4 & 55,6 & 44,5 \\
\hline \multicolumn{4}{c}{ Total } \\
\hline $\begin{array}{l}\text { Keterangan: } \\
\text { L= laki-laki; =perempuan; }\end{array}$ & 100,0 & 100,0 & 100,0 \\
\hline partisipan dapat memilih lebih dari satu sumber informasi
\end{tabular}



Keterpaparan Informasi. Menurut partisipan, sumber informasi terbanyak berasal dari media massa $(87,5 \%)$ dan teman $(70,8 \%)$ (Tabel 1). Proporsi terbesar partisipan $(44,5 \%)$ memperoleh informasi dengan frekuensi tidak tentu ( $\geq 1$ bulan sekali). Berdasarkan jenis kelamin, mahasiswa laki-laki cenderung lebih sering memperoleh informasi seputar pernikahan dan kehidupan keluarga dibandingkan dengan partisipan perempuan.

Faktor Stimulus. Salah satu faktor stimulus adalah teman sebaya. Pergaulan memungkinkan partisipan untuk berkomunikasi dengan teman sebaya. Sebagian besar partisipan $(93,1 \%)$ menyatakan pernah berdiskusi dengan teman mengenai pernikahan dan satu dari tiga diantaranya menunjukkan sikap biasa saja saat berdiskusi, hanya satu dari sepuluh partisipan yang sangat antusias ketika berdiskusi. Topik yang paling sering didiskusikan oleh partisipan dengan teman adalah mengenai kriteria pasangan (37.5\%) dan waktu menikah (36.1\%) (Tabel 2).

Hasil penelitian juga menunjukkan bahwa sebanyak 41,7 persen partisipan memiliki anggota keluarga yang menikah pada usia $<21$ tahun dan satu dari lima partisipan mempunyai pengalaman perceraian dalam keluarga. Tujuh dari sepuluh partisipan laki-laki maupun perempuan telah diajarkan cara mengelola rumah tangga oleh keluarganya. Bahkan sebagian besar keluarga partisipan $(81,9 \%)$ telah memberikan prasyarat tentang hal yang berkaitan dengan pernikahan.

Tabel 2 Sebaran partisipan berdasarkan stimulus teman sebaya

\begin{tabular}{|c|c|c|c|}
\hline Stimulus & $L(\%)$ & $\mathrm{P}(\%)$ & Total \\
\hline \multicolumn{4}{|c|}{ Diskusi pernikahan dengan teman } \\
\hline Pernah & 94,4 & 91,7 & 93,1 \\
\hline Tidak & 5,6 & 8,3 & 6,9 \\
\hline Total & 100,0 & 100,0 & 100,0 \\
\hline \multicolumn{4}{|l|}{ Sikap diskusi } \\
\hline Sangat antusias & 8,3 & 19,4 & 13,9 \\
\hline Senang & 47,2 & 36,1 & 41,7 \\
\hline Biasa saja & 44,4 & 44,4 & 44,4 \\
\hline Total & 100,0 & 100,0 & 100,0 \\
\hline \multicolumn{4}{|l|}{ Topik diskusi } \\
\hline Waktu menikah & 36,1 & 36,1 & 36,1 \\
\hline $\begin{array}{l}\text { Kriteria } \\
\text { pasangan }\end{array}$ & 38,9 & 36,1 & 37,5 \\
\hline $\begin{array}{l}\text { Rencana } \\
\text { pernikahan }\end{array}$ & 25,0 & 19,4 & 22,2 \\
\hline $\begin{array}{l}\text { Pengasuhan } \\
\text { anak }\end{array}$ & 0,0 & 8,3 & 4,2 \\
\hline Total & 100,0 & 100,0 & 100,0 \\
\hline
\end{tabular}

Tabel 3 Sebaran partisipan berdasarkan kategori pengetahuan tentang pernikahan dan jenis kelamin, nilai rata-rata dan standar deviasi, serta koefisien uji beda

\begin{tabular}{lccr}
\hline \multicolumn{1}{c}{ Kategori } & $\mathrm{L}(\%)$ & $\mathrm{P}(\%)$ & \multicolumn{1}{c}{ Total $(\%)$} \\
\hline Kurang & 19,4 & 16,7 & 18,1 \\
Sedang & 63,9 & 66,7 & 65,3 \\
Baik & 16,7 & 16,7 & 16,7 \\
\hline Total & 100,0 & 100,0 & 100,0 \\
Rata-rata \pm sd & $56,62 \pm$ & $57,35 \pm$ & $56,67 \pm$ \\
& 13,02 & 12,73 & 12,86 \\
p-value & & $0,001^{* *}$ & \\
\hline
\end{tabular}

Keterangan: $\mathrm{L}$ : laki-laki; $\mathrm{P}=$ perempuan

${ }^{* *}$ signifikan pada $p<0,01$

Pengetahuan tentang Pernikahan. Dua dari tiga partisipan memiliki pengetahuan tentang pernikahan pada kategori sedang. Rata-rata pengetahuan partisipan perempuan $(57,35)$ lebih tinggi dibandingkan dengan ratarata pengetahuan partisipan laki-laki $(56,62)$. Hal ini diperkuat juga dengan hasil uji statistik yang menunjukkan adanya perbeda-an yang nyata $(p<0,01)$ antara pengetahuan pernikahan partisipan laki-laki dan perempuan (Tabel 3 ). Kondisi demikian disebabkan karena partisipan perempuan lebih memprioritaskan menikah pada urutan lebih atas dibandingkan laki-laki, sehingga perempuan lebih mempersiapkan diri dengan memperluas pengetahuan tentang pernikahan.

Persepsi terhadap Pernikahan. Hasil penelitian menunjukkan bahwa sebagian besar partisipan $(70,8 \%)$ memiliki persepsi terhadap pernikahan pada kategori sedang. Hasil uji statistik juga menunjukkan bahwa tidak terdapat perbedaan yang nyata antara persepsi terhadap pernikahan pada partisipan laki-laki dan partisipan perempuan $(p>0,05)$. Sebaran partisipan berdasarkan kategori persepsi terhadap pernikahan disajikan pada Tabel 4.

Tabel 4 Sebaran partisipan berdasarkan kategori persepsi terhadap pernikahan dan jenis kelamin, nilai rata-rata dan standar deviasi, serta koefisien uji beda

\begin{tabular}{lccc}
\hline \multicolumn{1}{c}{ Kategori } & $\mathrm{L}(\%)$ & $\mathrm{P}(\%)$ & \multicolumn{1}{c}{ Total $(\%)$} \\
\hline Kurang & 16,7 & 11,1 & 13,9 \\
Sedang & 55,6 & 86,1 & 70,8 \\
Baik & 27,8 & 2,8 & 15,3 \\
\hline Total & 100,0 & 100,0 & 100,0 \\
& $73,03 \pm$ & $71,69 \pm$ & $72,36 \pm$ \\
Rata-rata \pm sd & 5,34 & 4,32 & 4,87 \\
Min-maks & $64-82$ & $63-82$ & $63-82$ \\
p-value & \multicolumn{3}{c}{0,248} \\
\hline \multicolumn{2}{l}{ Keterangan: L= laki-laki; P=perempuan }
\end{tabular}



Tabel 5 Sebaran partisipan berdasarkan persepsi terhadap kriteria siap menikah

\begin{tabular}{lrrr}
\hline Kriteria siap menikah* & L (\%) & P (\%) & $\begin{array}{c}\text { Total } \\
(\%)\end{array}$ \\
\hline Punya pekerjaaan & 88,9 & 89,0 & 89,0 \\
Sudah tamat kuliah & 25,0 & 50,0 & 38,0 \\
$\begin{array}{l}\text { Usia di atas 21 tahun } \\
\text { Pengetahuan yang }\end{array}$ & 41,7 & 53,0 & 47,0 \\
cukup & 77,8 & 86,0 & 82,0 \\
\hline
\end{tabular}

Keterangan:

$L=$ laki-laki; $P=$ perempuan

*partisipan dapat memilih lebih dari satu ciri

Persepsi terhadap Kriteria siap Menikah. Sebagian besar partisipan memilih "punya pekerjaan" $(89 \%)$ dan "pengetahuan yang cukup" (82\%) sebagai kriteria seseorang siap menikah (Tabel 5). Persepsi partisipan secara keseluruhan berarti menganggap bahwa kriteria seseorang yang siap menikah adalah mempunyai pekerjaan dan pengetahuan yang cukup tentang keluarga. Partisipan yang memilih kriteria "sudah tamat kuliah" merupakan proporsi terkecil $(38 \%)$ dibanding kriteria lainnya, dengan proporsi partisipan perempuan yang memilih $(50 \%)$ lebih besar dibandingkan partisipan laki-laki $(25 \%)$.

Kesiapan Menikah. Secara keseluruhan skor kesiapan menikah partisipan berkisar antara 65-90. Tabel 6 menunjukkan bahwa rata-rata partisipan baik laki-laki maupun perempuan cukup siap (77-87) masuk ke jenjang pernikahan.

Hubungan Antarvariabel. Pengetahuan tentang pernikahan berhubungan signifikan dengan usia $(p<0,05)$, jenis kelamin $(p<0,01)$, dan IPK $(0,01)$. Persepsi terhadap pernikahan berhubungan signifikan dengan jumlah saudara $(p<0,05)$ dan kebiasaan berdiskusi $(p<0,11)$. Kesiapan menikah berhubungan signifikan dengan frekuensi memperoleh informasi tentang pernikahan $(r=0,242, p<0,05)$.

Tabel 6 Sebaran partisipan berdasarkan kategori kesiapan menikah dan jenis kelamin, nilai rata-rata dan standar deviasi, serta koefisien uji beda

\begin{tabular}{lrrr}
\hline Kategori & $\begin{array}{r}\text { Laki- } \\
\text { laki }(\%)\end{array}$ & $\begin{array}{r}\text { Perempu- } \\
\text { an }(\%)\end{array}$ & $\begin{array}{c}\text { Total } \\
(\%)\end{array}$ \\
\hline Belum siap & 5,6 & 22,2 & 13,9 \\
Cukup siap & 75,0 & 55,6 & 65,3 \\
Siap & 19,4 & 22,2 & 20,8 \\
\hline \multicolumn{1}{c}{$\quad$ Total } & 100,0 & 100,0 & 100,0 \\
Rata-rata \pm std. & $83,1 \pm$ & $82,0 \pm 6,1$ & $82,6 \pm$ \\
deviasi & 4,6 & 5,4 \\
Min-maks & $70-90$ & $65-90$ & $65-90$ \\
p-value & & 0,399 & \\
\hline
\end{tabular}

Tabel 7 Koefisien regresi pengaruh karakteristik partisipan, keterpaparan informasi, faktor stimulus, dan pengetahuan terhadap persepsi tentang pernikahan

\begin{tabular}{|c|c|c|}
\hline Konstanta & Beta & Sig. \\
\hline Usia partisipan & $-0,157$ & 0,182 \\
\hline Jumlah saudara & $-0,245$ & $0,030^{*}$ \\
\hline $\begin{array}{l}\text { Frekuensi memperoleh } \\
\text { Informasi tentang } \\
\text { pernikahan dan } \\
\text { kehidupan keluarga }\end{array}$ & 0,136 & 0,218 \\
\hline $\begin{array}{l}\text { Diskusi pernikahan } \\
\text { dengan teman }\end{array}$ & 0,327 & $0,004^{* *}$ \\
\hline Pacar & $-0,231$ & $0,042^{*}$ \\
\hline $\begin{array}{l}\text { Cara mengelola rumah } \\
\text { tangga }\end{array}$ & 0,137 & 0,264 \\
\hline $\begin{array}{l}\text { Penekanan tentang } \\
\text { Pernikahan oleh } \\
\text { keluarga }\end{array}$ & $-0,186$ & 0,118 \\
\hline $\begin{array}{l}\text { Adjusted R Square } \\
F(p)\end{array}$ & $\begin{array}{r}0 \\
3,322 \\
\end{array}$ & $\left.04^{\mathrm{a}}\right)$ \\
\hline
\end{tabular}

Keterangan :

* Signifikan pada $p<0,05$; ** Signifikan pada $p<0,01$

Pengaruh Karakteristik Partisipan, Keterpaparan Informasi, Faktor Stimulus, dan Pengetahuan terhadap Persepsi tentang Pernikahan. Model persamaan regresi yang disusun memiliki koefisien determinasi (adjusted $\mathrm{R}$ square) sebesar 0,186. Artinya, 18,6 persen varian persepsi terhadap pernikahan dapat dijelaskan oleh perubahan variabel-variabel yang ada di dalam model. Hasil analisis regresi linier berganda menunjukkan bahwa hanya variabel jumlah saudara $(\beta=-0,245, p<0,05)$, diskusi pernikahan dengan teman $(\beta=0,327, p<0,01)$, dan pacar $(\beta=-0,231, p<0,05)$ yang berpengaruh signifikan terhadap persepsi pernikahan (Tabel 7).

Pengaruh Karakteristik Partisipan, Keterpaparan Informasi, Faktor Stimulus, Pengetahuan, dan Persepsi terhadap Kesiapan Menikah. Model persamaan regresi yang disusun memiliki koefisien determinasi (adjusted R square) sebesar 0,176 (Tabel 8). Artinya, 17,6 persen varian persepsi terhadap pernikahan dapat dijelaskan oleh perubahan variabel-variabel yang ada di dalam model. Berdasarkan hasil uji regresi linier berganda, ada tiga variabel yang berpengaruh nyata terhadap kesiapan menikah. Variabel tersebut adalah usia partisipan $(\beta=-0,273, \quad p<0,05)$, jumlah penyakit yang diderita $(\beta=-0,287$, $p<0,05)$, dan cara mengelola rumah tangga $(\beta=0,249, p<0,05)$ (Tabel 8). Cara mengelola rumah tangga berpengaruh positif terhadap kesiapan menikah, sedangkan usia dan jumlah penyakit yang diderita berpengaruh negatif terhadap kesiapan menikah. 

Tabel 8 Koefisien regresi pengaruh karakteristik partisipan, keterpaparan informasi, faktor stimulus, pengetahuan, dan persepsi terhadap kesiapan menikah

\begin{tabular}{|c|c|c|}
\hline Konstanta & Beta & Sig. \\
\hline Usia partisipan & $-0,273$ & $0,047^{*}$ \\
\hline Jumlah saudara & $-0,102$ & 0,379 \\
\hline Uang saku per bulan & $-0,136$ & 0,245 \\
\hline $\begin{array}{l}\text { Jumlah penyakit yang } \\
\text { diderita }\end{array}$ & $-0,287$ & $0,016^{*}$ \\
\hline Prioritas menikah & 0,185 & 0,123 \\
\hline $\begin{array}{l}\text { Pengetahuan partisipan } \\
\text { tentang pernikahan }\end{array}$ & 0,032 & 0,785 \\
\hline $\begin{array}{l}\text { Persepsi terhadap } \\
\text { pernikahan }\end{array}$ & $-0,034$ & 0,787 \\
\hline $\begin{array}{l}\text { Frekuensi memperoleh } \\
\text { informasi tentang } \\
\text { pernikahan dan kehidupan } \\
\text { keluarga }\end{array}$ & 0,164 & 0,180 \\
\hline $\begin{array}{l}\text { Diskusi pernikahan } \\
\text { dengan teman }\end{array}$ & 0,179 & 0,140 \\
\hline $\begin{array}{l}\text { Sikap saat berdiskusi } \\
\text { dengan teman }\end{array}$ & 0,121 & 0,328 \\
\hline Pacar & $-0,131$ & 0,308 \\
\hline $\begin{array}{l}\text { Cara mengelola rumah } \\
\text { tangga }\end{array}$ & 0,249 & $0,048^{*}$ \\
\hline Suku & 0,191 & 0,116 \\
\hline $\begin{array}{l}\text { Pengalaman keluarga } \\
\text { menikah di bawah usia } 21 \\
\text { tahun }\end{array}$ & 0,234 & 0,068 \\
\hline Adjusted R Square & \multicolumn{2}{|c|}{0,176} \\
\hline$F(p)$ & \multicolumn{2}{|c|}{$2,083\left(0,027^{a}\right)$} \\
\hline
\end{tabular}

\section{PEMBAHASAN}

Mahasiswa memiliki persepsi yang berbeda terkait pernikahan. Partisipan menempatkan menikah sebagai prioritas kedua. Prioritas pertama partisipan adalah bekerja. Partisipan menganggap bahwa individu dikatakan siap menikah jika telah memiliki pekerjaan dan pengetahuan yang cukup. Dengan demikian, pengetahuan dinilai sebagai salah satu aspek yang cukup penting dalam pernikahan.

Pengetahuan yang dimiliki partisipan terkait pernikahan tergolong dalam kategori sedang. Analisis korelasi menunjukkan bahwa pengetahuan berhubungan signifikan dengan dengan jenis kelamin. Partisipan yang berjenis kelamin perempuan memiliki pengetahuan pernikahan yang lebih baik dibandingkan dengan partisipan berjenis kelamin laki-laki. Blood (1969) juga mengemukakan bahwa perempuan lebih tertarik untuk mengurus rumah tangga. Sesuai dengan sifat feminisme, perempuan memiliki peran sebagai pengurus rumah tangga, sehingga secara tidak langsung dituntut untuk mempunyai pengetahuan yang lebih terkait pernikahan dan keluarga.

Pengetahuan juga berhubungan signifikan dengan usia dan IPK. Semakin tinggi IPK partisipan maka semakin baik pengetahuan yang dimilikinya terkait pernikahan. IPK sebagai salah satu indikator kecerdasan kognitif di perguruan tinggi. Seperti yang dinyatakan Susantoro, diacu dalam Siregar (2006), sosok mahasiswa kental dengan nuansa kedinamisan dan sikap keilmuannya dalam melihat sesuatu berdasarkan kenyataan objektif, sistematis, dan rasional demikian juga halnya dengan pengetahuan tentang pernikahan.

Pengetahuan merupakan faktor internal seseorang yang dapat mempengaruhi terbentuknya persepsi. Akan tetapi, hasil penelitian ini menunjukkan bahwa pengetahuan yang dimiliki partisipan tentang pernikahan tidak berhubungan signifikan dengan persepsi partisipan terhadap pernikahan. Persepsi partisipan terhadap pernikahan berhubungan signifikan dengan jumlah saudara. Jumlah saudara yang semakin banyak, maka informasi yang didapat dari pengalaman ataupun peristiwa menjadi lebih banyak, sehingga persepsi partisipan terhadap pernikahan tergantung pada cara partisipan menafsirkan pesan yang diterima. Peristiwa yang telah dilalui seseorang akan menentukan kecermatan persepsi (Rakhmat, 2005).

Persepsi terhadap pernikahan juga berhubungan signifikan dengan kebiasaan berdiskusi. Mahasiswa membentuk representasi internal tentang konsep menikah dan nilai-nilai yang dianut dari informasi yang diperoleh sebelumnya. Informasi ini bisa berasal dari keluarga, teman, atau pengalaman orang lain (Putrini, 2002). Mahasiswa lebih banyak menghabiskan waktunya di kampus sehingga secara tidak langsung tersedia lebih banyak waktu untuk berkomunikasi dengan teman dibandingkan keluarga. Hal yang dikomunikasikan tidak lepas dari masalah pribadi dan berkaitan dengan pasangan, sehingga secara tidak langsung terbangun persepsi terhadap pernikahan.

Keterpaparan informasi, faktor stimulus, pengetahuan tentang pernikahan, dan persepsi terhadap pernikahan diduga berhubungan dengan kesiapan menikah. Akan tetapi, hasil penelitian menunjukkan bahwa kesiapan menikah berhubungan signifikan dengan frekuensi partisipan memperoleh informasi. Semakin sering individu memperoleh informasi maka individu tersebut akan semakin siap 

untuk menikah. Hal ini sejalan dengan Calhoun dan Acocella (1995) yang menyatakan bahwa massa sangat terpengaruh oleh yang dikatakan media. Media memiliki pengaruh yang besar dalam mengubah dan membentuk persepsi dan sikap baru.

Hasil uji regresi menunjukkan bahwa usia berpengaruh terhadap kesiapan. Hal ini sejalan dengan Puspitasari (1997) yang menyatakan bahwa usia menikah, motivasi untuk menikah, karakteristik kepribadian yang matang, dan penyesuaian diri yang baik berpengaruh terhadap kesiapan menikah. Selain usia, kesiapan menikah dipengaruhi oleh cara mengelola rumah tangga. Kesiapan menikah akan meningkat dengan semakin diajarkannya cara mengelola rumah tangga.

Kesiapan menikah juga dipengaruhi oleh jumlah penyakit yang diderita. Kesiapan menikah akan menurun dengan meningkatnya jumlah penyakit yang diderita. Menurut Dewi (2006), kondisi kesehatan seorang individu juga turut mempengaruhi kesiapannya untuk memasuki jenjang pernikahan. Individu yang merasa dirinya kurang atau tidak memiliki kondisi kesehatan yang prima cenderung ragu untuk melangkah menuju jenjang pernikahan.

\section{SIMPULAN DAN SARAN}

Hasil penelitian menunjukkan bahwa pengetahuan tentang pernikahan berhubungan signifikan dengan usia, jenis kelamin, dan IPK. Persepsi tentang pernikahan berhubungan signifikan dengan jumlah saudara dan kebiasaan berdiskusi. Persepsi tentang pernikahan dipengaruhi oleh jumlah saudara, diskusi pernikahan dengan teman, dan pacar. Kesiapan menikah berhubungan signifikan dengan frekuensi memperoleh informasi tentang pernikahan. Kesiapan menikah dipengaruhi oleh usia, jumlah penyakit yang diderita, dan cara untuk mengelola rumah tangga. Penelitian lanjutan disarankan juga mengkaji variabel lain, seperti motivasi menikah, kematangan emosi, dan kepribadian.

\section{DAFTAR PUSTAKA}

Blood, R. O. (1969). Marriage ( $2^{\text {nd }}$ ed). New York.
Calhoun, J.F., \& Acocella, J.R.(1995). Psikologi tentang Penyesuaian dan Hubungan Kemanusiaan. Ed ke-3. RS Satmoko, penerjemah. Semarang: IKIP Semarang Press. Terjemahan dari: Psychology of Adjustment and Human Relationships.

Desiyani, F. (2003). Faktor-Faktor yang Mempengaruhi Persepsi dan Sikap Mahasiswa IPB tentang Kepemimpinan Laki-laki dan Perempuan: Suatu Pendekatan Analisis Gender [skripsi]. Bogor: Fakultas Pertanian, Institut Pertanian Bogor.

Dewi, I.S. (2006). Kesiapan Menikah Pada Wanita Dewasa Awal yang Bekerja. [terhubung berkala]. Tersedia pada: www.library.usu.ac.id. [diunduh 16 Februari 2009].

Hawa, S. (2007). Siap-siap Nikah. Depok: PT Lingkar Pena Kreative.

Kenedi, G. (2005). Model Konseling Pranikah Berorientasi Pengembangan Konsep Diri [ringkasan disertasi]. Bandung: Universitas Pendidikan Indonesia.

Maria, U. (2007). Peran Persepsi Keharmonisan Keluarga dan Konsep Diri terhadap Kecenderungan Kenakalan Remaja [tesis]. Yogyakarta: Universitas Gadjah Mada.

Puspitasari, A. (1997). Adaptasi Alat Ukur Kesiapan Perkawinan California Marriage Readiness Evaluation (adaptasi, uji reliabilitas dan validitas pada kelompok sampel dewasa muda) [skripsi]. Depok: Fakultas Psikologi, Universitas Indonesia.

Putrini, A. (2002). Pengambilan Keputusan untuk Menikah dan Tidak Menikah Saat Masa Kuliah pada Mahasiswi [skripsi]. Depok: Universitas Indonesia.

Rakhmat, J. (2005). Psikologi Komunikasi: Bandung: Penerbit Remaja Rosdakarya.

Siregar, A. R. (2006). Motivasi Berprestasi Mahasiswa ditinjau dari Pola Asuh. [terhubung berkala]. Tersedia pada: www.library.usu.ac.id [diunduh pada 4 April 2009]. 